\title{
Improving the Student Conceptual Understanding of the Static Fluid Material by Using the Model of Children Learning in Science
}

\author{
Eka Murdani \\ Physics Education \\ STKIP Singkawang \\ Singkawang-79251, Indonesia \\ ekamurdani@gmail.com
}

\author{
Sumarli \\ Physics Education \\ STKIP Singkawang \\ Singkawang-79251, Indonesia \\ sumarliphysics@gmail.com
}

\author{
Buyung \\ Mathematics Education \\ STKIP Singkawang \\ Singkawang-79251, Indonesia \\ 21.buyung@gmail.com
}

\begin{abstract}
This study aims to illustrate the increasing understanding of student concepts through the application of Children Learning In Science (CLIS) models on static fluid materials. This research was conducted in one of Singkawang high schools on static fluid material especially the concept of hydrostatic pressure, Pascal law, and Archimedes law. This form of research is pre-experiment with one group pre-test-post-test design. The object of this research is all students of class $\mathrm{XI}$ in one of Singkawang high school which is determined by using saturated sampling technique. Improved conceptual understanding was measured using a multiple choice test of conceptual understanding that had previously been tested. The results showed an increase in students' understanding of concept ability with $\mathrm{N}$-gain value of 0.60 (medium category).
\end{abstract}

Keywords-Children Learning In Science; Conceptual Understanding; Static Fluid

\section{INTRODUCTION}

Physics is the science that is built on the basis of conclusions from various natural phenomena that students learn [1]. Physics is studied in schools to facilitate students to be able to master and understand the concepts or theories of physics and develop their thinking skills and skills. This goal shows that the main stage of studying physics is to understand the concept [2].

The foundation that students must master from learning the concept of physics is an understanding of the concept. Understanding is the result of a learning process that has indicators and each person can explain or define a piece of information in their own words [3]. The same thing also expressed by Reference [4], that the ability of students' understanding will be seen if they are able to construct the meaning of the subject matter in the form of oral communication, writing, and graphics. Students are able to understand a new knowledge when they are able to build a relationship between new knowledge integrated with the scheme and cognitive that they already have.

Based on the description, it can be concluded that understanding is an important aspect in physics learning, because this ability helps students to translate, interpret and conclude a physics concept based on the formation of their knowledge. In addition, students can find and explain the connection of a concept with other concepts and help students develop their ability to apply concepts from what they have learned.

In reality, based on the results of observations made in one of the Senior High Schools of Singkawang, the physics learning process tends to be teacher oriented. The concept that should be found directly through the experience of the teacher with experiments or demonstrations carried out in the classroom did not happen much. In line with Reference [5-6], the current learning process is only related to acceptance and lack of discovery process by involving students. In addition, there are still students who are less active. This lack of active students usually occurs in those who have difficulty understanding and developing their thinking skills [7-8].

This opinion is supported by the results of the test of the students' understanding of the concept of physics subject matter while doing the pre-research obtained an average score of 25.6 from the maximum score of 100. These results indicate that the students' understanding of the concept of physics is still weak. The fact that learning like that makes students do not understand well the explanation conveyed by the teacher, especially in difficult physics understandings. In the end, the learning makes students feel bored and lacks interest in students to engage in learning activities [9]. This causes most students from the beginning to study physics having difficulty recognizing key concepts of basic concepts or the relationship between physical concepts [10].

On the basis of the results of the preliminary study, it is necessary to change the quality of effective and efficient learning, as an alternative to increasing student involvement in 
learning activities and concept planting activities directly so that learning becomes meaningful.

One learning model that can be used as an alternative in learning is the CLIS model. This learning model can help students broaden students' conceptual understanding through the given problems and can form new scientific (concept) knowledge [11].

This learning model has characteristics based on generative learning [12]. Where the learning process helps students in developing their knowledge and can optimize the active role of students in the teaching and learning process so as to minimize the emergence of negative activities and facilitate the inculcation of physical concepts [13]. This makes the CLIS model one of the alternative learning models suitable for maximizing the concept of planting [14].

According to Reference [15] in general, CLIS has stages which consist of orientation, the appearance of ideas, rearrangement of ideas, the application of ideas and review of ideas. This stage is organized in such a way as to achieve the learning objectives of increasing the ability to understand students' concepts.

The stage starts from the stage of the emergence of ideas in the CLIS model can develop students' understanding of the aspects of interpreting and exemplifying. In the drafting stage, the ideas of students are trained to develop aspects of explaining, interpreting, comparing, concluding and exemplifying. At the application stage ideas, students can develop aspects explaining. The stage of reviewing students can develop aspects of summarizing, concluding and comparing [13].

In the orientation phase, the teacher conducts demonstration activities to get the students' attention. The stage of the emergence of ideas, students access their initial knowledge. Reordering ideas, students discussing, conveying the results of the discussion and exchanging ideas. Students find scientific concepts from various ideas of students by conducting experimental activities. The application phase of ideas, students apply concepts and develop concepts into new situations. The stage of reviewing changes in ideas, providing reinforcement by conducting question and answer activities and reviewing so that the knowledge built by students is aligned with scientific concepts [16]. From the background, the researcher wants to know and get an idea of improving students' conceptual understanding after applying the CLIS model.

\section{METHOD}

This research is a quantitative research with the research method used is pre-experiment with the design of one group pre-test-post-test design. The population of this study was all students of class XI Science in one of the Singkawang Senior High Schools with sampling taken using techniques sampling saturated. The selection of this technique is due to only one class XI so that the entire population is used as a research sample.
Data collection techniques used in this study test students' understanding of concepts with multiple choice questions containing static fluid material. The instrument used is the sheets pretest and posttest. Before being tested on the object to be studied, the instrument was tested to determine the level of difficulty, differentiation, and reliability.

The test results are then analyzed to find out the improvement of students' conceptual understanding of the static fluid material by using the $\mathrm{N}$-gain (Equation 1) with Criteria for N-gain in Table I.

$$
\langle g\rangle=\frac{S_{\text {posttest }}-S_{\text {pretest }}}{S_{\max }-S_{\text {pretest }}}
$$

TABLE I. CRITERIA FOR N-GAIN

\begin{tabular}{|c|c|}
\hline Value & Categories \\
\hline$<\mathrm{g}>\geq 0,7$ & High \\
$0,3 \leq<\mathrm{g}><0,7$ & Medium \\
$<\mathrm{g}><0,3$ & Low \\
\hline
\end{tabular}

\section{RESULT AND DISCUSSION}

\section{A. Result}

Results of students' conceptual understanding was measured using questions conceptual understanding consisting of aspects of interpreting, exemplifying, comparing, concluding, explaining, and summarizing. After getting the results of the data pretest and posttest, then analyzed by $\mathrm{N}$ gain test. Based on the calculation results obtained an average score of students' concept comprehension test after normalization obtained an increase of 0.60 in the medium category.

Based on the aspect of understanding the concept of students, the improvement data for each aspect has two categories, namely high and medium. As for the results of understanding the concept can be seen in Table II.

TABLE II. IMPROVING OF CONCEPTUAL UNDERSTANDING ASPECTS

\begin{tabular}{|c|c|}
\hline $\begin{array}{c}\text { Aspects of Conceptual } \\
\text { Understanding }\end{array}$ & Categories \\
\hline Interpreting & High \\
\hline Exemplifying & Medium \\
\hline Comparing & Medium \\
\hline Concluding & Medium \\
\hline Explaining & Medium \\
\hline Summarizing & Medium \\
\hline
\end{tabular}

The number of masses of every aspect of understanding concepts measured as much as 66 points. In the aspect of interpreting, there was an increase in the score of pre-test to post-test by 31 points, in the aspect of exemplifying an increase of 25 points, in the aspect of comparing there was an increase of 29 points, while in the aspect of concluding an increase of 24 and in the aspect of explaining an increase of 28 , and in aspect summarizes an increase of 11 points. The 
diagram of the increase in pre-test to post-test scores can be seen in Figure 1.

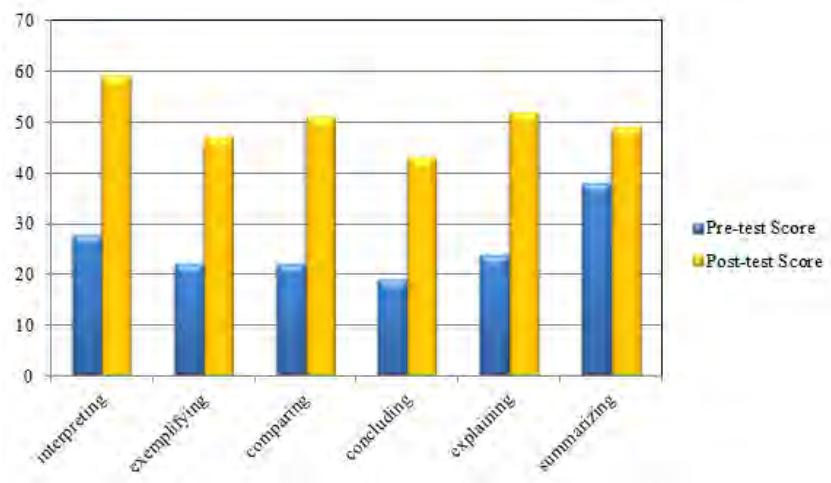

Fig. 1. Improving Score of Pre-test to Post-test

Improvement in every aspect of concept understanding was analyzed using the N-gain test. In the interpreting aspect an increase of 0.82 with the high category, in the exemplifying aspect there was an increase of 0.57 with the medium category, in the aspect of comparing there was an increase of 0.66 with the medium category, in the aspect concluding there was an increase of 0.51 with the medium category, in the explaining aspects an increase of 0.67 with the medium category, and summarizing aspects an increase of 0.41 with the medium category after the use of the CLIS model in the learning process on static fluid material. As for N-gain, every aspect of concept understanding can be seen in Figure 2.

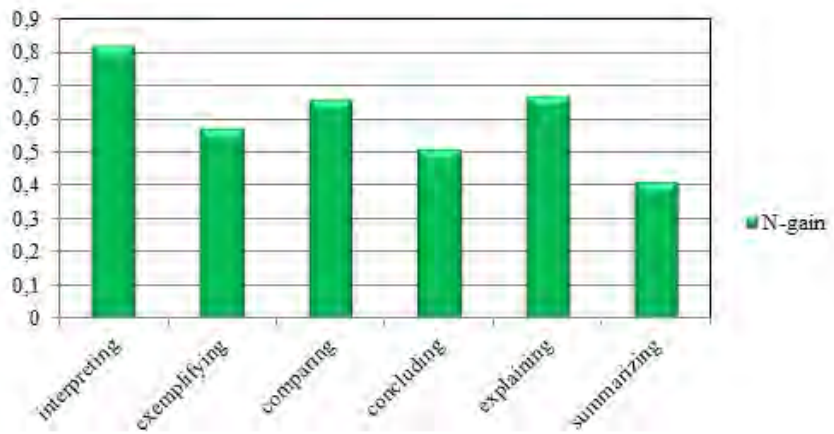

Fig. 2. N-gain of Conceptual Understanding

\section{B. Discussion}

Based on the results of the analysis, it turns out that the use of the CLIS model can improve students' conceptual understanding of the material being studied. The CLIS model can enhance students' conceptual understanding because the learning process allows students to train their conceptual understanding skills.

This increase can occur due to the CLIS model students have the opportunity to actively express ideas related to the material being studied, exchange and compare ideas between individuals and discuss to equate perceptions, students have the opportunity to investigate and develop students' ideas/ideas on a problem which later the idea was constructed based on observations or experiments [13]. Inviting students to look for scientific concepts makes the learning process meaningful and students can understand the concepts learned [17].

Improved students' understanding of concepts is obtained using the $\mathrm{N}$-gain equation that is equal to 0.60 in the medium category. Where concept understanding of students has increased in every aspect. In the interpreting aspect, there is an increase in the high category because students are given the opportunity with the group to change an information from one form to another. With the opportunity of students in dialogue, students are not reluctant to ask questions and discuss in an effort to change every available information into another form [18]. In the aspect of explaining, exemplifying, summarizing, concluding and comparing there is an increase in the low category.

Reference [19] said that there was an increase in these aspects because students were asked to write their ideas (claims) which contained answers to the problems given and in the answers must include evidence and the reasons that connected them. To get the truth about their ideas can be done with the activity of investigation or data collection. In collecting evidence or data students are directed to find relevant examples. Then compare the data obtained between groups. When differences occur, they are provoked to express ideas openly so that the causes of differences in data or information can be identified.

After that, students are able to propose statements that represent the presentation of information or summaries of the material [13]. At the end of learning, students are able to conclude problem-solving and integrate it with knowledge or material learned [18].

\section{CONCLUSION}

Based on the results of the study and discussion, it can be concluded that using the CLIS model in the physics learning process, especially in the static fluid material can improve students' understanding of concepts with $\mathrm{N}$-gain results of 0.60 in the medium category.

\section{REFERENCES}

[1] I. Wicaksono, B. Jatmiko, and T. Prastowo, "Pengembangan Perangkat Pengembangan Fisika Model Learning Cycle $5 E$ untuk Meningkatkan Pemahaman Konsep Siswa pada Materi Fluida Statis", Jurnal Pendidikan Sains Pascasarjana Universitas Negeri Surabaya, Vol. 4, No. 2, pp. 518-52, Mei 2015.

[2] K.E.N. Soge, "Analisis Pemahaman Konsep Vektor pada Siswa Kelas X SMA BOPKRI 1 Yogyakarta”, Doctoral Dissertation, Program Pascasarjana Universitas Sanata Darma, Yogyakarta, 2016. Unpublished.

[3] F. Alatas, "Hubungan Pemahaman Konsep dengan Keterampilan Berpikir Kritis melalui Model Pembelajaran Treffinger pada Mata Kuliah Fisika Dasar", Jurnal EDUSAINS, Vol. 01, 2014, pp. 88-96.

[4] W.L. Anderson, and R.D. Krathwohl, "A Taxonomy for Learning, Teaching and Assesing. A Revision of Bloom's Taxonomy of Educational Objective", New York: Addison Wesley Longman, 2001.

[5] A. Purnomo, "Penggunaan Metode POE dalam Pembelajaran Fisika untuk Meningkatkan Pemahaman Konsep dan Kesenangan tentang Hukum Archimedes dalam Fluida Statis di Kelas XI IPA SMA 
Tarakanita Magelang”, Doctoral Dissertation, Program Sarjana Universitas Sanata Darma, Yogyakarta, 2015, Unpublished.

[6] Sumarli, S.E. Nugroho, and I. Yulianti, "Keefektifan Model Pembelajaran Creative Problem Solving Berpendekatan Inquiry terhadap Keterampilan Proses Sains Siswa", Physics Communication, Vol. 2, No. 1, 2018, pp. 63-69.

[7] I.D. Kurniawati, Wartono, and Diantoro, "Pengaruh Pembelajaran Inkuiri Terbimbing Intergrasi Peer Instruction terhadap Penguasaan Konsep dan Kemampuan Berpikir Kritis Siswa", Jurnal Pendidikan Fisika Indonesia, Vol. 10, 2014, pp. 36-46.

[8] Sumarli, “Analisis Model Pembelajaran Tipe Think-Pair-Share Berbasis Pemecahan Masalah terhadap Keterampilan Berpikir Tingkat Tinggi Siswa", Jurnal Ilmu Pendidikan Fisika, Vol. 3, No. 1, 2018, pp. 8-13.

[9] M. Kostelnikova, and M. Ozvoldova, "Inquiry in Physics Classes by Means of Remote Experiments", Procedia-Social and Behavioral Sciences Journal, Vol. 89, 2013, pp. 133-138.

[10] M. Ihsanudin, "Penggunaan Peta Konsep Berbantuan Multimedia untuk Meningkatkan Pemahaman Konsep Fisika Siswa SMP”. Doctoral Dissertation, Program Sarjana FPMIPA Universitas Pendidikan Indonesia, Bandung, 2013. Unpublished.

[11] Y. Kendek, "Penerapan Model Pembelajaran Children Learning In Science (CLIS) untuk Meningkatkan Hasil Belajar Fisika pada Siswa Kelas XI SMA Negeri 8 Palu", Jurnal Pendidikan Fisika Tadulako, Vol. 2, No. 3, 2014.

[12] N.Y. Laili, K.I. Mahardika, and A.A. Ghani, "Pengaruh Model Children Learning In Science (CLIS) disertai LKS Berbasis Multirepresentasi terhadap Aktivitas Belajar Siswa dan Hasil Belajar Siswa dalam Pelajaran Fisika di SMA Kabupaten Jember", Jurnal Pendidikan Fisika, Vol.4, No. 2. 2015.
[13] N.M.S. Asshagab, "Penerapan Model Pembelajaran Children's Learning In Science (CLIS) untuk Meningkatkan Keterampilan Proses Sains dan Pemahaman Konsep Hukum Newton Siswa", Doctoral Dissertation, Program Pascasarjana Universitas Pendidikan Indonesia, Bandung, 2012. Unpublished.

[14] A.A.Gst.I. Dewi, Md.I. Suarjana, and N.Pt. Riastini, "Pengaruh Model Pembelajaran CLIS terhadap Pemahaman Konsep IPA Siswa Kelas V SD di Gugus VII Kecamatan Sawan", Jurnal Pendidikan Guru Sekolah Dasar FIP, Universitas Ganesha, Singaraja, Vol. 20, No. 1, 2014.

[15] R. Driver, "Changing Conceptions", Journal Research In Education, 1988, pp. 161-196.

[16] A. Rahmadina, N. Hermita, and H. Syahrifuddin, "Penerapan Model Children Learning In Science (CLIS) untuk Meningkatkan Hasil Belajar IPA Kelas VB SD Negeri 97 Pekanbaru", Jurnal PGSD FKIP Universitas Riau, 2012.

[17] A. Ismail, "Penerapan Model Pembelajaran Children Learning In Science (CLIS) Berbantuan Multimedia untuk Meningkatkan Penguasaan Konsep Fisika Siswa SMA”, Jurnal Pendidikan Teknologi dan Informasi, PETIK Vol. 1, No. 1, 2015, pp 19-25.

[18] A. Nuryandi, and D. Rusdiana, "Penerapan Dialogical Argumentation Isntructional Model (DAIM) untuk Meningkatkan Pemahaman dan Kemampuan Argumentasi Siswa SMA pada Materi Listrik Statik", Jurnal, 2016, pp 76-83.

[19] K. Sundari, and Nurmalasari, "Pengaruh Model Pembelajaran Children Learning In Science terhadap Penguasaan Konsep Siswa pada Mata Pelajaran Ilmu Pengetahuan Alam Kelas III Di Sekolah Dasar Negeri III Bekasi”, PEDAGOGIK Vol. 1, No. 1, 2013, pp. 80-88. 